\title{
原子間力顕微鏡による $\mathrm{Si}$ と Ge 表面での原子操作
}

\author{
森田清三 ${ }^{*},{ }^{* *}$ ・杉本宜昭 ${ }^{*}$ - 大藪範昭 ${ }^{*} \cdot$ Óscar CUSTANCE ${ }^{* *}$ \\ 西 竜治 ${ }^{* *}, *$ ・清野宜秀 ${ }^{* *}$ ・李 仁淑 ${ }^{* *}$ ・阿部真之 ${ }^{*} *^{* *}$ \\ ${ }^{*}$ 大阪大学大学院工学研究科電気電子情報工学専攻 馬 565-0871 大阪府吹田市山田丘 2-1 \\ **阪大フロンティア研究機構 桥565-0871 大阪府吹田市山田丘 2-1 \\ *** 大阪大学大学院工学研究科原子分子イオン制御理工学センター 寀 565-0871 大阪府吹田市山田丘 2-1
}

（2005 年 1 月 5 日受理）

\author{
Atom Manipulation on Si and Ge Surfaces \\ using Atomic Force Microscope \\ Seizo Morita ${ }^{*}, *{ }^{*}$, Yoshiaki Sugimoto ${ }^{*}$, Noriaki Oyabu ${ }^{*}$, Óscar Custance ${ }^{*}$, \\ Ryuji NISHI $^{* * *}, *$, Yoshihide SEINO ${ }^{* *}$, In Sook YI ${ }^{* *}$ and Masayuki AbE ${ }^{*}, * *$ \\ * Department of Electrical, Electronic and Information Engineering, Graduate School of Engineering, Osaka University, \\ 2-1 Yamadaoka, Suita, Osaka 565-0871 \\ ${ }^{*}$ * Handai Frontier Research Center (Handai FRC), 2-1 Yamadaoka, Suita, Osaka 565-0871 \\ ${ }^{* * *}$ Science and Technology Center for Atoms, Molecules, and Ions Control (STAMIC), Graduate School of Engineering, \\ Osaka University, 2-1 Yamadaoka, Suita, Osaka 565-0871
}

(Received January 5, 2005)

In this review article, at first, we introduced recent developments of powerful and sensitive atomic force microscope (AFM). Then, we introduced recent three topics related to AFM. The first one is an atom selective imaging of semiconductor surfaces with intermixed $\mathrm{Si}$ and $\mathrm{Sn}$ adatoms at room temperature (RT), i.e., chemical discrimination of two atom species on semiconductor surfaces at RT. The second one is vertical and lateral atom manipulations of semiconductor atoms based on the mechanical method at low temperature (LT). The last one is a novel atom manipulation method that enables us to create complex nanostructures assembled from more than two atom species at RT. Using this novel atom manipulation method, we constructed "Atom Inlay" at RT, i.e., atom letters "Sn" consisting of Sn atoms embedded in Ge atoms.

\section{1. は じめに}

高性能・高感度原子間力顕微鏡 $(\mathrm{AFM})^{1,2}$ ) は, 日進 月歩で進化している。2002 年の 3 月号で「非接触原子 間力顕微鏡一なにがどこまで見えるか?一」を特集 ${ }^{3)}$ たときと現在とで, いつの間にか, 天と地との差ほどの 性能差ができてしまった。例えば, 神戸大学の笹原らに よる 1 気圧窒素ガス中での真の原子・分子分解能観察 ${ }^{4}$ や京都大学の福間らによる大気圧中・水溶液中での真の

E-mail: smorita@ele.eng.osaka-u.ac.jp
原子・分子分解能観察5)の実現により, AFM は, 超高 真空だけでなく大気圧中や溶液中でも真の原子・分子分 解能観察が可能となり, 使用環境や応用分野の急激な拡 大が起こりつつある。また, 北陸先端大の新井らによる バイアス電圧印加を利用した新しい原子間力顕微分光法 の発見(6)により, 原子分解能での電子状態やバンド構造 研究への新たな道が拓ける可能性が出てきている。ここ で紹介する元素識別 $\left.{ }^{7}, 8\right)$, 凹凸の周辺原子種効果 ${ }^{8)}$, 低 温での垂直 ${ }^{9)}$ ・水平原子操作 ${ }^{10)}$, 室温での「交換型原子 操作」11) るだけでなく, 識別しつつ操作して複雑なナノ構造を組 


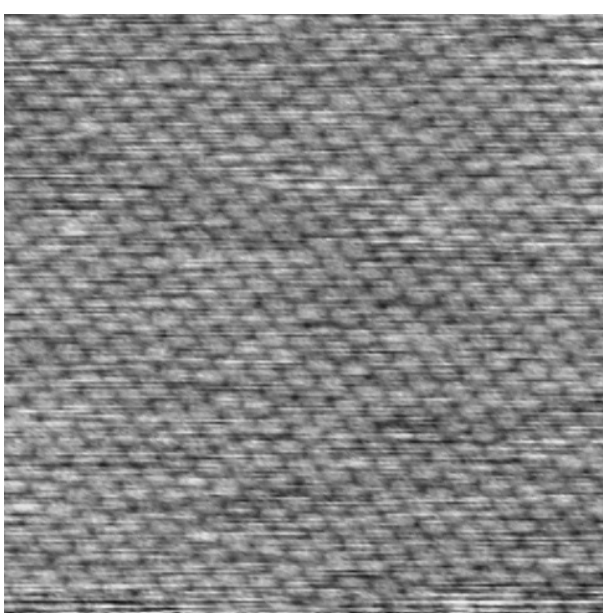

(a)

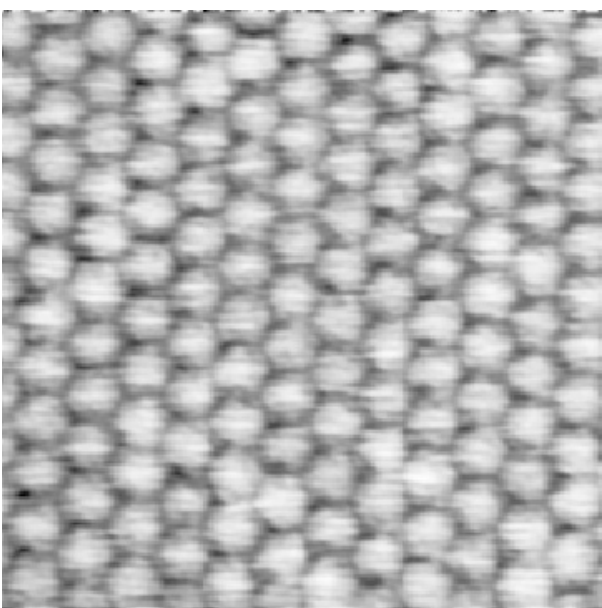

(b)

Fig. 1. (a) NC-AFM image of $\mathrm{NaF}(100)$ cleaved surface at RT $(7.8 \mathrm{~nm} \times 8.5 \mathrm{~nm}, \Delta \mathrm{f}=$ $-10.3 \mathrm{~Hz}, \mathrm{~A}=33 \mathrm{~nm}$ ). The surface was made by cleavage in air and heated at $650 \mathrm{~K}$ in vacuum. (b) NC-AFM image of $\mathrm{CaF}_{2}$ thin film on $\mathrm{Si}(111)$ at $\mathrm{RT}(4.1 \mathrm{~nm} \times 4.1 \mathrm{~nm}$, $\Delta \mathrm{f}=-17.5 \mathrm{~Hz}, \mathrm{~A}=7.5 \mathrm{~nm})$.

み立てられることを直接示すものである。

\section{2. 非接触原子間力顕微鏡（NC-AFM）で何 がどこまで見えるか？}

NC-AFM の大きな特徵は, 走査型トンネル顕微鏡 （STM）では測定できない絶縁体表面でも原子分解能が 得られることである。Fig. 1 (a) は NaF（100）表面を NC-AFM で超高真空中, 室温で観察した原子像で $\mathrm{F}^{-}$イ オンの像と推定されている1)。Fig. 1（b）は Si(111）面 上に蒸着した $\mathrm{CaF}_{2}$ (111) 面の室温での $\mathrm{NC}-\mathrm{AFM}$ 原子像 で，テコ先端に付着した $\mathrm{CaF}_{2}$ の微粒子の $\mathrm{F}^{-}$イオンが試 料側に突き出ており, その結果, $\mathrm{Ca}^{2+}$ イオンの $\mathrm{NC}-\mathrm{AFM}$ 像が得られたものと推定できる ${ }^{2)}$ 。 $\mathrm{Ca}^{2+}$ イオンが試料側 に突き出た微粒子がテコ先端に付着した場合は, Fig. 1 （b）とは異なる NC-AFM 像が得られる1)。

従来，NC-AFM の空間分解能は一般に STM より劣る と考えられてきた。この原因は, 原子間力の距離依存性 がトンネル電流の距離依存性より弱いためである。しか し, 最近, 距離依存性が弱い原子間力でも高感度に測定 できるようになってきた結果，試料側の測定量の空間的 拡がりが空間分解能を律速する段階に到達しつつある。 この段階では, STM で測定する電子は空間的に拡がる 傾向が強く, 他方, NC-AFM で測定する原子間力は空 間的に局在する傾向が強いため, 測定する試料によって は NC-AFM の方が STM より高分解能な画像が得られ始 めている12)。Fig. 2 は, $S i(111) 7 \times 7$ 上に吸着した Ge 原子のクラスターの低温（78 K） での NC-AFM 像であ るが, $\mathrm{Si}$ (111) 7×7 上に吸着した 1 層目と 2 層目の $\mathrm{Ge}$

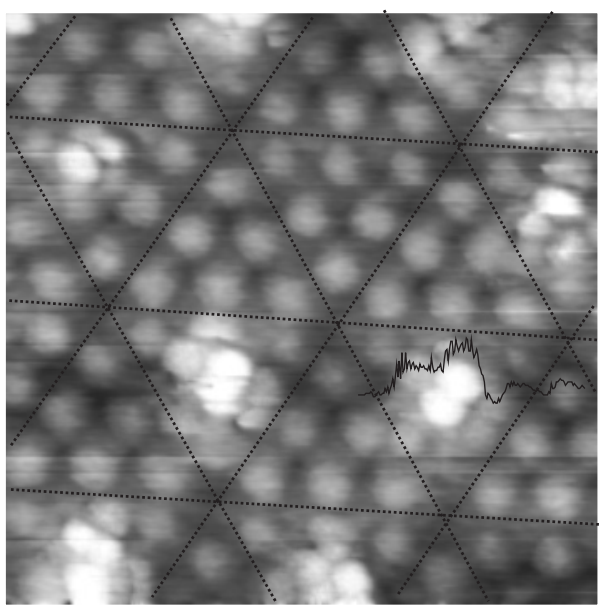

Fig. 2. NC-AFM Image of self-assembled Ge atom clusters on $\mathrm{Si}(111) 7 \times 7$ observed at $78 \mathrm{~K}(6.9 \mathrm{~nm} \times 6.9 \mathrm{~nm}$, $\Delta \mathrm{f}=-26.8 \mathrm{~Hz}, \mathrm{~A}=10 \mathrm{~nm}$, RT 3 min deposition, $300{ }^{\circ} \mathrm{C} 10$ min annealing).

原子が明膫に区別して観察されており，STMによる像 と較べて遜色のない空間分解能が達成されている。

\section{3. 半導体表面の個々の原子の元素識別と凹 凸の周辺原子種効果}

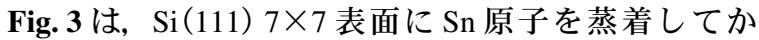
らアニールして得た, $\mathrm{Sn} / \mathrm{Si}(111) \sqrt{3} \times \sqrt{3}$ 混在表面の室 温での NC-AFM 像である。Fig. 3 (a)-(c) では明暸な $\sqrt{3} \times \sqrt{3}$ 構造だけでなく, 明るい輝点と相対的に暗い輝 点の 2 種類の輝点が観察される。これら 2 種類の輝点は, 混在した Si 原子と Sn 原子に対応すると考えられる。Fig. 


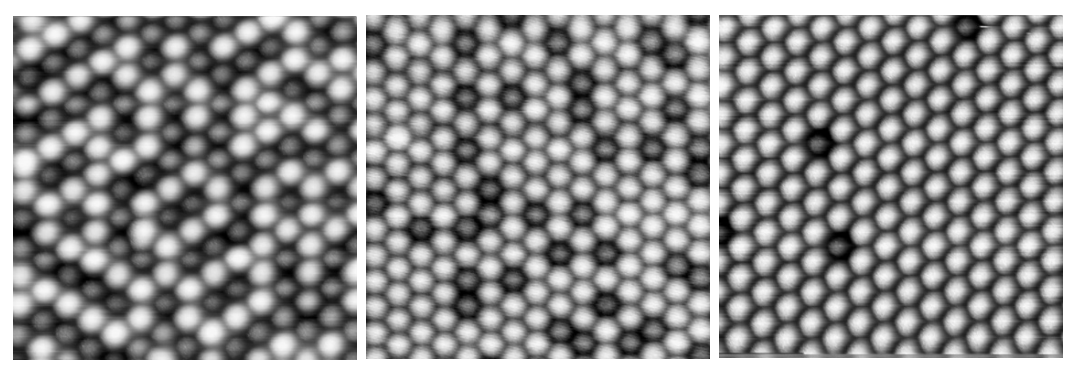

(a)

(b)

(c)

Fig. 3. NC-AFM images of $\operatorname{Sn} / \operatorname{Si}(111)-(\sqrt{3} \times \sqrt{3})$ surfaces at RT. (a) mosaic phase (Sn: $1 / 6 \mathrm{ML}, \mathrm{Sn}: 50 \%$, Si: $50 \%)(8.0 \mathrm{~nm} \times 8.0 \mathrm{~nm}, \Delta \mathrm{f}=-2.9 \mathrm{~Hz}$, $\mathrm{A}=19 \mathrm{~nm}),(\mathrm{b})$ intermediate phase (Sn: 1/4 ML, Sn: $80 \% \mathrm{Si}: 20 \%)(8.0$ $\mathrm{nm} \times 8.0 \mathrm{~nm}, \Delta \mathrm{f}=-5.1 \mathrm{~Hz}, \mathrm{~A}=24 \mathrm{~nm})$, (c) pure phase $(\mathrm{Sn}: 1 / 3 \mathrm{ML}$, Sn: $99 \% \mathrm{Si}: 1 \%)(8.0 \mathrm{~nm} \times 8.0 \mathrm{~nm}, \Delta \mathrm{f}=-4.7 \mathrm{~Hz}, \mathrm{~A}=20 \mathrm{~nm})$.

3 (a)-(c) では, Sn 原子の蒸着量を下地の $\mathrm{Si}(111) 1 \times 1$ に対して 1/6 ML, 1/4 ML, 1/3 ML と増やしており, そ の結果, 明るい輝点が明瞭に増加していることより, 明 るい輝点が Sn 原子で, 相対的に暗い輝点が Si 原子であ ることが判明した。 $\sqrt{3} \times \sqrt{3}$ 構造では $\operatorname{Si}(111) 1 \times 1$ に対 して $1 / 3$ ML の Sn 原子の蒸着量で表面全体を Sn 原子が 覆うため, Fig. 3 (a) の Sn 原子蒸着量が 1/6 ML では, $\mathrm{Sn}$ 原子と Si 原子の混在量が半々でモザイク相ができ ている。他方, Fig. 3 (c) の Sn 原子の蒸着量が 1/3 ML では, Sn 原子がほぼ全面を覆っており, ごく少数の $\mathrm{Si}$ 原子のみが混在している。

Fig. 4 (a) は, Fig. 3 (c) の各原子の高さの分布をヒ ストグラムで調べたもので, ほぼ全面を覆っている $\mathrm{Sn}$ 原子とごく少数の Si 原子のピークが見られる。このヒ ストグラムの解析により我々の NC-AFM の垂直空間分 解能が見積もられる。つまり本来等価であるはずの $\mathrm{Sn}$ 原子が $2 \mathrm{pm}$ の標準偏差を持つ高さ分布を示すことよ り, 我々の NC-AFM の垂直空間分解能が $2 \mathrm{pm}$ と見積も ることができる。他方, Fig. 4（b）は, Fig. 3（a）の各 原子の高さ分布のヒストグラムであるが, Sn 原子と Si 原子のピークが分離されているものの, 明らかに高さの ばらつきが大きくなっている。この高さのばらつきは再 現性があり, Si 原子の方が Sn 原子よりも高さのばらつ きが大きい。そこで, 個々の $\mathrm{Si}$ 原子や $\mathrm{Sn}$ 原子の高さと 隣接する 6 個の原子中の $\mathrm{Sn}$ 原子の数との相関を調べ た。その結果, Fig. 5 に示すように, 個々の Si 原子の高 さは, 6 個の隣接原子中に含まれる Sn 原子数の増加と 共に明瞭に減少する傾向を見出した ${ }^{8)}$ 。この結果は, 個々 の $\mathrm{Si}$ 原子の高さは, 隣接する 6 個の原子中の $\mathrm{Sn}$ 原子数 に強く依存することを示す。このような隣接原子種とそ の数に依存する個々の原子の高さ変化は, $\mathrm{Si}$ 原子から $\mathrm{Sn}$ 原子への電荷移動に伴う原子位置の緩和や探針との結合

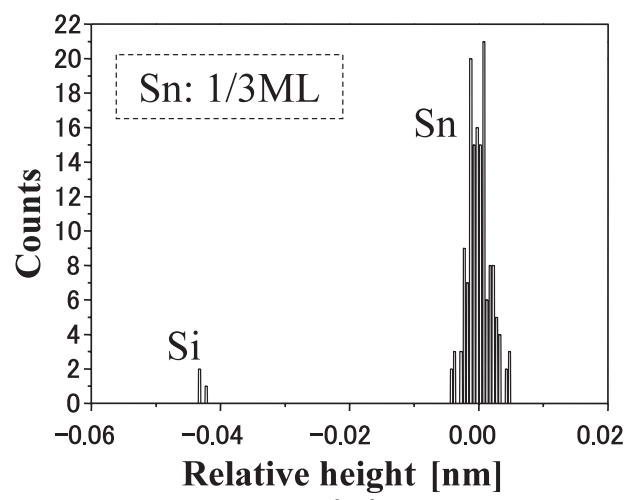

(a)

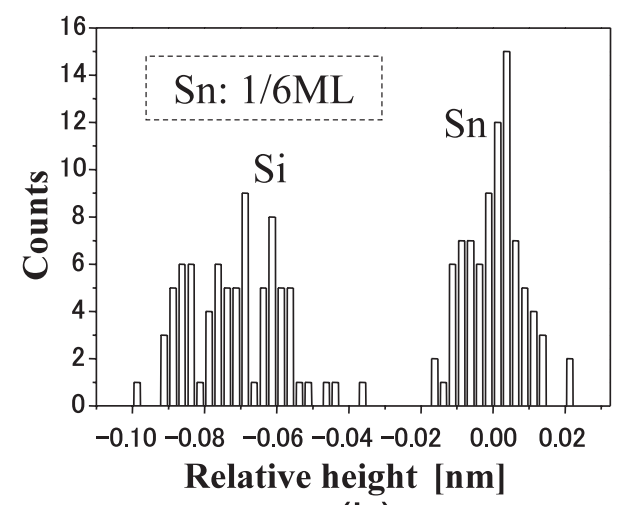

(b)

Fig. 4. Histograms of atomic corrugations in $\mathrm{Sn} / \mathrm{Si}(111)$ $(\sqrt{3} \times \sqrt{3})$ surfaces at RT. (a) pure phase (Sn: $1 / 3$ ML, Sn: $99 \%$ Si: 1\%), (b) mosaic phase (Sn: 1/6 ML, Sn: $50 \%$ Si: $50 \%$ ).

力の変化で説明される8)。つまり, NC-AFM で測定され る個々の原子の凹凸は, 周辺原子との直接的・間接的な 化学結合や電荷移動や原子レベルの応力による波動関数 や原子間力や歪の変化などを反映したものであることを 直接示すものである。 


\section{4. 半導体表面への垂直原子押し込みによる 低温での表面ナノ構造の創製}

最近，低温の AFM で $\mathrm{Si}$ のテコ先端を $\mathrm{Si}$ (111) 7×7 表面の Si 原子に押し込んで Si 原子を力学的に除去した り，除去した $\mathrm{Si}$ 原子の空孔にテコ先端を押し込んで $\mathrm{Si}$ 原子を付与して原子空孔（欠陥）を修復できることを示 した ${ }^{9}$ 。その後, Ge(111)-c $(2 \times 8)$ 表面で同様な実験を 行った結果, Fig. 6 のような, 複数回の垂直原子押し込 みによる表面ナノ構造の創製と改変に $79 \mathrm{~K}$ の低温で成 功した。最初に, Fig. 6（a）中の黒い矢印の Ge 原子に 探針 $\mathrm{Si}$ 原子を押し込んだ結果，（b）のように，垂直原

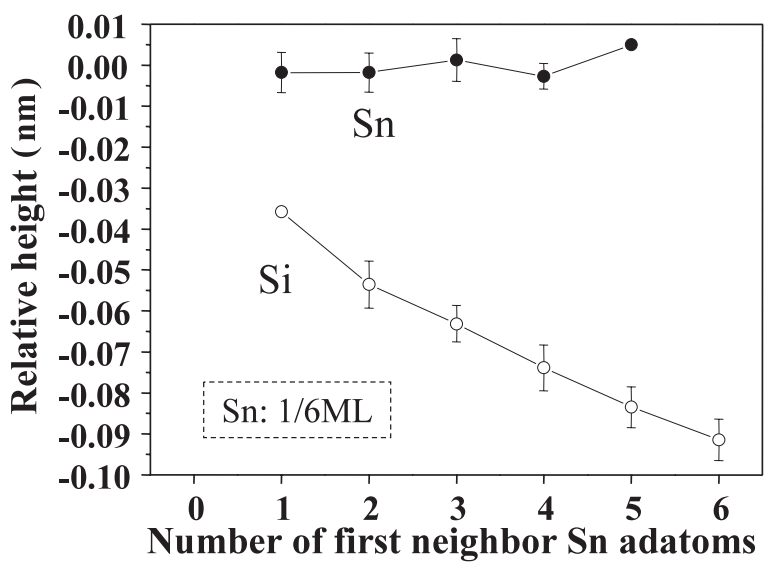

Fig. 5. Relative heights of $\mathrm{Si}$ and $\mathrm{Sn}$ atoms as a function of number of first neighbor $\mathrm{Sn}$ adatoms in $\mathrm{Sn} / \mathrm{Si}(111)-$ $(\sqrt{3} \times \sqrt{3})$ mosaic phase (Sn: $1 / 6 \mathrm{ML}, \mathrm{Sn}: 50 \% \mathrm{Si}$ : $50 \%)$.
子操作で押し込まれた $\mathrm{Ge}$ 原子が引き抜かれると同時に 水平原子操作も起こり, 引力で引き抜かれた $\mathrm{Ge}$ 原子に 隣接した $\mathrm{Ge}$ 原子が半格子だけ水平移動した。水平移動 した Ge 原子は（b）では不安定だが，再度測定した（c) では安定化しており, $\mathrm{c}(2 \times 8)$ 再構成表面中の黒い矢印 の押し込み部分周辺に，1 回の垂直原子押し込みで 3 個 の $\mathrm{Ge}$ 原子からできた（擬似）正三角形の表面ナノ構造 が創製できた。次に，(c) 中の黒い矢印の $\mathrm{Ge}$ 原子に探 針 $\mathrm{Si}$ 原子を押し込んだ結果，（d）のように，押し込ま れた $\mathrm{Ge}$ 原子が水平原子操作で半格子だけ逆に水平移動 した。水平移動した $\mathrm{Ge}$ 原子は（d）では少し不安定だ が，再度测定した（e）では安定化しており，3 個の $\mathrm{Ge}$ 原子からできた正三角形の表面ナノ構造を 2 回目の垂直 原子押し込みにより直角三角形に改変できた。さらに,

（e）中の黒い矢印の空孔（Ge 原子欠陥）に探針 Si 原子 を押し込んだ結果，(f) のように，人工的に作成した $\mathrm{Ge}$ 原子欠陥を修理することに成功した。このように，垂直 原子押し込みだけで, $\mathrm{Ge}$ 原子を垂直に引き抜く（除去） だけでなく，さらには水平移動させることや，原子を原 子欠陥に堆積 (付与) して欠陷を修理することも可能で, その結果, 複数回の垂直原子押し込みにより表面ナノ構 造の創製や改変ができる。

\section{5. 探針先端の走査による半導体表面上に吸 着した原子の低温水平原子操作}

4 節で述べた探針先端の垂直原子押し込みでは，原子 の除去や付与や水平移動などの多種の現象が起こり，制 御性や再現性が不十分であった。また，垂直原子押し込

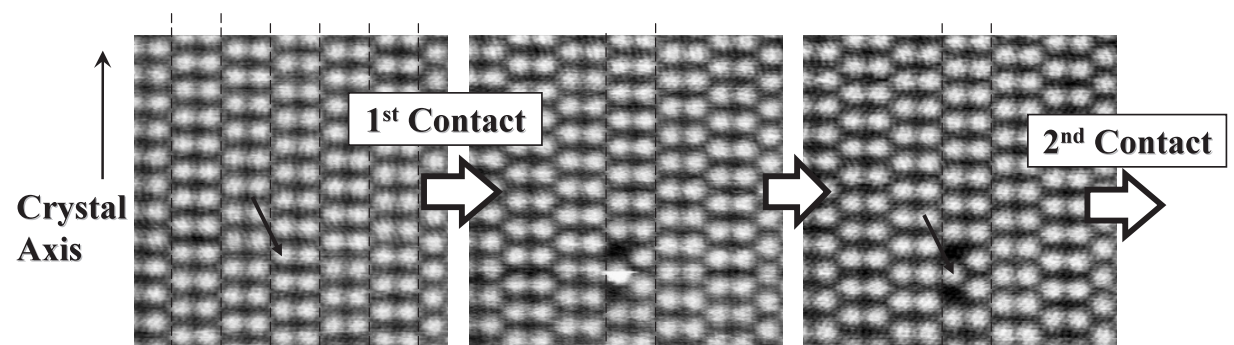

(a)

(b)

(c)

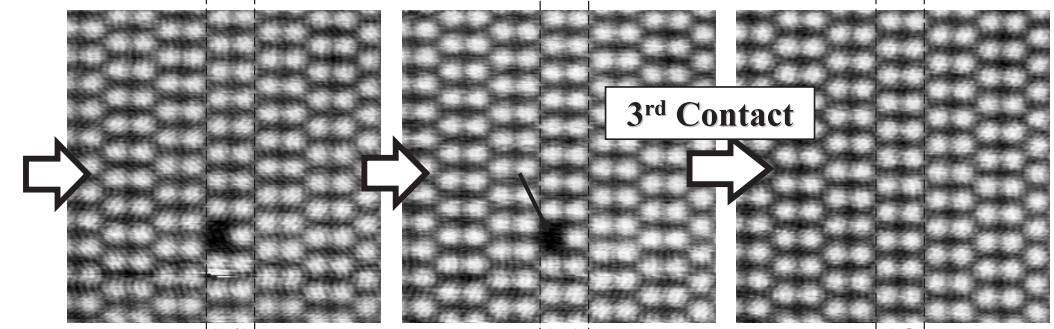

(d)

(e)

(f)

Fig. 6. Sequential NC-AFM images of $\mathrm{Ge}(111) \mathrm{c}(2 \times 8)$ before and after three soft nanoindentations to the sites indicated by black arrows in (a), (c) and (e) at $79 \mathrm{~K}(9 \mathrm{~nm} \times 9 \mathrm{~nm})$. 


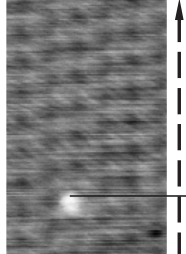

(a)

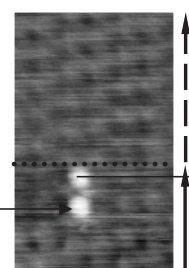

(b)

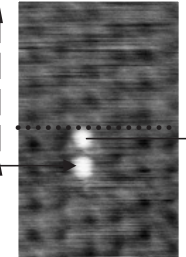

(c)

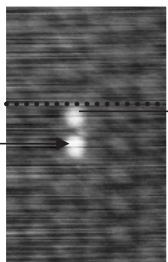

(d)

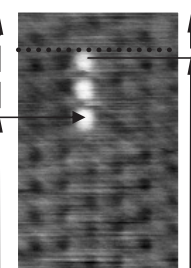

(e)

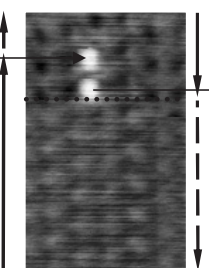

(f)

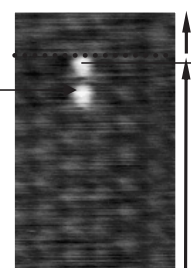

(g)

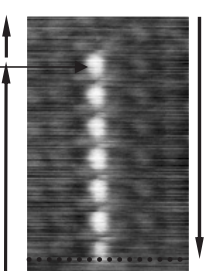

(h)

Fig. 7. Sequential noncontact- and nearcontact-AFM images of $\mathrm{Ge}(111) \mathrm{c}(2 \times 8)$ at $79 \mathrm{~K}$. Black broken arrows show noncontact-AFM regions obtained at $\Delta \mathrm{f}=-28 \mathrm{~Hz}$, while black solid arrows show nearcontact-AFM regions obtained at $\Delta \mathrm{f}=-31 \mathrm{~Hz}$ where successive lateral scan contacts induced repeated jumps and repeated imaging of adsorbed single atom. Black arrows also show slow scan directions. $2.2 \mathrm{~nm} \times 3.5 \mathrm{~nm}, \mathrm{~A}=9.3 \mathrm{~nm}$.

みでは, 挆針先端の原子や結合状態が変化しやすい問題 もあった。そこで, 探針先端の走査による半導体表面上 に吸着した原子の低温水平原子操作の実験を試みた ${ }^{10)}$ 。

Fig. 7 (a) は，周波数シフトが- $28 \mathrm{~Hz}$ ，探針-試料間引 力が $0.8 \mathrm{nN}$, 温度が $79 \mathrm{~K}$ の条件下で測定した $\mathrm{Ge}(111)$ $\mathrm{c}(2 \times 8)$ 表面の NC-AFM 像であるが, $\mathrm{c}(2 \times 8)$ 表面上 に 1 個の原子 (輝点) が吸着していることが明膫に観察 できる。次に，探針-試料間距離を約 $6 \mathrm{pm}$ 近づけて周 波数シフトを- $31 \mathrm{~Hz}$ ，探針一試料間引力を $1.0 \mathrm{nN}$ にし て, 探針-試料間引力を約 $0.2 \mathrm{nN}$ 増加して，(b) の NCAFM 像右側の黒い実線の矢印部分に対応する NC-AFM 像の範囲を再度測定した結果, NC-AFM 像中に輝点が 2 つ見えた。これは，1個の同じ原子(輝点) が探針-試 料間引力で等価な吸着位置間をジャンプして 2 回画像化 されたものと考えられる。実際，(b) の黒い点線部分で 周波数シフトを- $28 \mathrm{~Hz}$ ，探針一試料間引力を $0.8 \mathrm{nN}$ に 戻した結果，黒い破線の矢印部分に対応する NC-AFM 像の範囲には輝点が現れなかった。このような，探針一 試料間引力を調節した水平操作により，(b)，(c)，(d) や（g) のように 1 回だけジャンプを起こしたり，(e) のように 2 回ジャンプを起こしてから止めたり, 低速走 查の方向を逆転して (f) や (h) のように逆方向に 1 回 あるいは 6 回ジャンプさせたりできた。なお，吸着原子 が動き終わったジャンブ後の位置を NC-AFM 像中の横 方向の黒い実線の矢印の始点で, 次の NC-AFM 像で吸 着原子が動き始めるジャンプ前の位置を黒い実線の矢印 の終端（先端）部分で示しているが，位置が完全に一致 していることが明膫である。Fig. 7 の結果は，STMによ る金属表面の吸着原子や分子の実験13) と同様に, AFM でも, 探針試料間引力を調節した低温での探針の水平 走查により, 半導体表面上に吸着した原子を結晶軸方向 に等価な吸着位置間をジャンプさせて自由に水平原子操 作できることを示す。このような, 引力下での水平原子 操作の利点は制御性や再現性が良く, また, 探針のダメ

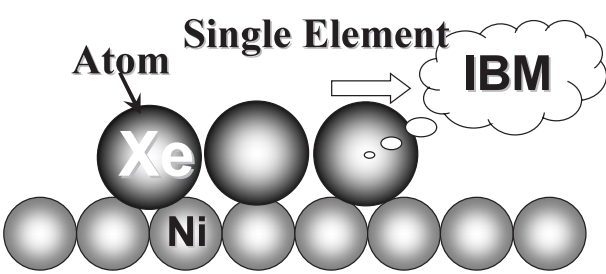

(a)

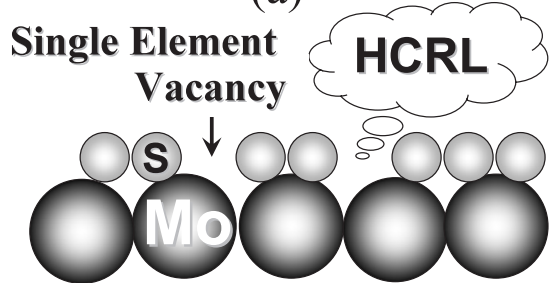

(b)

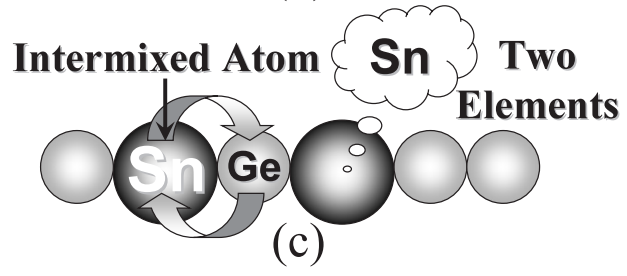

Fig. 8. Models of atom letters fabricated by preceding and our groups. (a) IBM group, (b) Hitachi group and (c) our group.

ージがまったくないことである。

\section{6. 交換型原子操作と室温での原子埋め込み 文字の創製}

単原子操作のデモンストレーションとして一般的なの は, 原子で字を書く, つまり原子文字の創製である。STM で特に有名なのは, Fig. 8（a）のような，IBM の D.M. Eigler らによる $\mathrm{Ni}$ (110) 基板上に物理吸着させた Xe 原 子をファン・デル・ワールスカで水平原子操作して $4 \mathrm{~K}$ で「IBM」という字を描いた 1990 年の世界初の原子文 字の創製である14)。その翌年の 1991 年には，（b）のよ うな, 日立の細木らにより，電界蒸発を用いた垂直原子 


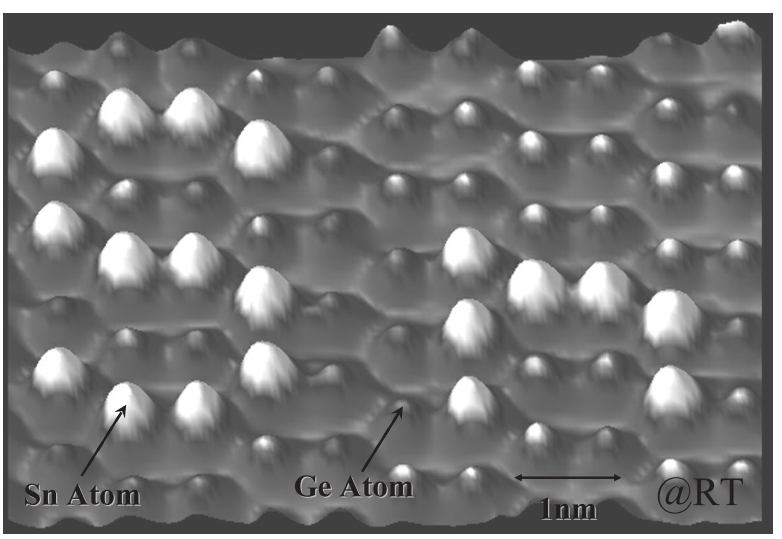

Fig. 9. "Atom Inlay" figured by AFM at RT: Atom letters consisted of $\mathrm{Sn}$ atoms embedded in $\mathrm{Ge}(111) \mathrm{c}(2 \times 8)$ surface.

操作で $\mathrm{MoS}_{2}$ へき開面から $\mathrm{S}$ 原子を引き抜いて室温で 「PEACE'91 HCRL」という原子文字が描かれている15)。 前者は, Xe 原子を動かして原子文字を描いているが, 極低温環境下で行われており, しかも単一の元素しか動 かしていない。後者は, 室温で $\mathrm{S}$ 原子を引き抜いて原 子文字を描いているが，単一の元素しか動かしていない だけでなく，空孔で原子文字を描いている。また，両方 とも，導電性の基板しか観察できない STM を用いてい る。

最近，我々は絶縁体にも応用できる AFM を用いて, 単元素ではなく，2 種類の元素の位置を同時に交換する 新しい原子操作の手法である交換型原子操作を発見し, 室温で, Fig.9のような原子文字を描くことに成功し た ${ }^{11)}$ 。具体的には, Fig. 8 (c) に示すように, AFM の 挆針先端原子を試料表面に近づけて走査することによ り, $\mathrm{Ge}(111) \mathrm{c}(2 \times 8)$ 基板に埋め込んだ $\mathrm{Sn}$ 原子と $\mathrm{Ge}$ 原 子の位置を交換し，それを繰り返し行うことにより，「原 子埋め込文文字 (原子象嵌)」, すなわち, Ge 原子中に 埋め込んだ Sn 原子で書いた「Sn」の原子文字の室温に おける創製に成功した。

\section{7.おわりに}

高性能・高感度原子間力顕微鏡（AFM）は，日進月 歩で進化している。距離依存性が弱い原子間力でも高感 度に測定できるようになってきた結果，STM で測定す る電子は空間的に拡がる傾向が強く, 他方, AFM で測 定する原子間力は空間的に局在する傾向が強いため, 測 定する試料によっては AFM の方が STM より高分解能 な画像が得られ始めている。また, 絶縁体や半導体等の 表面を原子レベル観察できるだけでなく, 異なる元素を
識別しさらに周辺原子との直接的・間接的な化学結合や 電荷移動や原子レベルの応力による波動関数や原子間力 や歪の変化などを個々の原子レベルで凹凸変化などとし て，測定可能になってきた。さらに，低温での力学的な 垂直・水平原子操作で，個々の原子の除去や付与や水平 移動により，原子レベルのナノ構造創製も可能となって きた。特に注目すべき点は，室温で異種原子の位置を交 換する交換型原子操作の発見により，合金・混晶・不純 物半導体・セラミクスのような多種類の元素を用いた複 素材料からなる複雑で高機能・多機能な新規ナノ構造体 の室温での創製・探索に道が拓かれたことである。絶縁 体も扱える AFM により室温で新奇なナノ材料，ナノデ バイスを創製する世界レベルの探索競争が，今後，急激 に激化するものと思われる。

\section{文 献}

1) S. Morita, R. Wiesendanger and E. Meyer (Eds.): "Noncontact Atomic Force Microscopy" (NanoScience and Technology Series, Springer-Verlag, Berlin, Heidelberg, New York, 2002).

2) 森田清三編著：“原子・分子のナノ力学” (丸善株式 会社, 2003).

3) 森田清三, 菅原康弘：表面科学 23, 132 (2002).

4) A. Sasahara, S. Kitamura, H. Uetsuka and H. Onishi: J. Phys. Chem. B 108, 15735 (2004).

5) T. Fukuma, T. Ichii, K. Kobayashi, H. Yamada and K. Matsushige: Appl. Phys. Lett. 86, 034103 (2005).

6) T. Arai and M. Tomitori: Phys. Rev. Lett. 93, 256101 (2004).

7) S. Morita, Y. Sugimoto, N. Oyabu, R. Nishi, Ó. Custance, Y. Sugawara and M. Abe: J. Electron Microsc. 53, 163 (2004).

8) Y. Sugimoto, M. Abe, K. Yoshimoto, Ó. Custance, I. Yi and S. Morita: Appl. Surf. Sci. 241, 23 (2005).

9) N. Oyabu, Ó. Custance, I. Yi, Y. Sugawara and S. Morita: Phys. Rev. Lett. 90, 176102 (2003).

10) N. Oyabu, Y. Sugimoto, M. Abe, Ó. Custance and S. Morita: Nanotechnology 16, S 112 (2005).

11) Y. Sugimoto, M. Abe, S. Hirayama, N. Oyabu, Ó. Custance and S. Morita: Nature Materials 4, 156 (2005).

12) T. Eguchi, Y. Fujikawa, K. Akiyama, T. An, M. Ono, T. Hashimoto, Y. Morikawa, K. Terakura, T. Sakurai, M.G. Lagally and Y. Hasegawa: Phys. Rev. Lett. 93, 266102 (2004).

13) L. Bartels, G. Meyer and K.-H. Rieder: Phys. Rev. Lett. 79, 697 (1997).

14) D.M. Eigler and E.K. Schweizer: Nature 344, 524 (1990).

15) 細木茂行，保坂純男，長谷川剛：表面科学 12, 623 (1991). 